\title{
Sariswara Method as the Basis of Art Lesson in Tamansiswa
}

\author{
Harpang Yudha Karyawanto \\ Universitas Negeri Surabaya \\ Surabaya, Indonesia \\ harpangkaryawanto@unesa.ac.id
}

\author{
Noordiana \\ Universitas Negeri Surabaya \\ Surabaya, Indonesia \\ noordiana@unesa.ac.id
}

\begin{abstract}
This research aims at revealing Sariswara method in reinforcing children's character in Tamansiswa Yogyakarta. The objectives of this research were: (1) analyzing the implementation of Sariswara method in Tamansiswa Yogyakarta; (2) analyzing the effect of Sariswara method towards the children's character in Tamansiswa Yogyakarta. This research used descriptive qualitative design with textual and contextual studies. The data were collected through library studies, interview, and observation. The result showed that Tamansiswa was a formal educational institution which used art as a mean of education, aiming at balancing the intellectual aspect and character. In running the education system, Tamansiswa used Among system or Tutwuri Handayani which gave far-ranging freedom for the students to develop their personal discipline and their personal character normally that benefitted themselves and their surroundings. One specialized teaching method for art education in Tamansiswa Yogyakarta was Sariswara method. The effect of the method was reinforcing the students' character. In this case, they experienced positive changes in terms of attitude and behavior such as having confidence, discipline, togetherness, understanding ethics and aesthetics, having independence, being intelligent, and creative.
\end{abstract}

\section{Keywords-Sariswara method; art lesson; tamansiswa}

\section{INTRODUCTION}

Various innovations in improving learning at schools have appeared through new methods of teaching. Of course, it starts from early age level. Art is a learning, primary medium of which uses movements and songs as known until today. In selecting the adopted song, teachers have to be selective. They need to adapt the theme with the rhythms and notes so that the students will be easier to memorize and imitate what have been developed through the movements and song. A qualified educational product cannot be separated from the role of teachers in the process of learning. Teachers are demanded to be able to create an atmosphere for learning which is active, creative, innovative, effective, and fun. Learning strategy is an important tool in the hands of a professional teacher. Strategy therefore could be referred to as a plan, procedure, approach or style of instruction [8]

The existence of art education started developing before Indonesia was free. Tamansiswa was an initial milestone for art education in Indonesia. From the historical facts, it cannot be denied that Tamansiswa has completed many educational activities intentionally with art elements. Tamansiswa becomes an institution which strikes for culture and development using education with the extended meaning as a medium. Therefore, in its application, art can be manifested in some activities in education field. Hence, it is normal in the past, in which most schools had not involved art in education plan, Tamansiswa was labelled as an educational institution which was prominent in art that art was strongly embedded into it. One of the proofs is that Tamansiswa once conducted a special meeting to discuss art education issues in 1954. Conducting a meeting is an effort of education aiming at educating and giving opportunity for students to develop their aesthetic sense based on their talents in line with the real character so that they will be aesthetic human beings who are active and have characters [10].

As an institution of culture struggle, Tamansiswa strikes for certain cultural values so that they can be manifested into society's daily life. The cultural values raised by Tamansiswa comprise values, conceptions, and life attitude towards simplicity, honesty, clannish, freedom of soul, nationality, Tutwuri Handayani, Among behavior, Among education system, national education, democratic education, trilogy of leadership (ing ngarsa sung tuladha, ing madya mangun karsa, tut wuri handayani), three education centers, Trikon theory, and peaceful society [13].

Based on the historical facts, Tamansiswa is an institution pioneering Among education system or Among method. Among system is an education system with clannish and it consists of two bases, nature and freedom fate. This system is also called Tutwuri Handayani system. It includes every activity carried out in the institution and schools holistically. Tutwuri Handayani system does not only deal with methodological aspect but also teaching-learning process or education process involving human interaction, that is between teachers and students.

In Tamansiswa, art education is included in the curriculum so that the students do not only have intelligent but also aesthetic sense awareness as well as morality and character. In addition, by including art education in curriculum, it is expected that schools are able to manure and develop the students' talents based on their own character. Tamansiswa's curriculum is different from other schools in general which put art lesson as part of extracurricular program. Art lesson in most schools generally focus on the knowledge of art itself, not the main point of learning art dealing with developing art sensitivity. Such phenomenon can be caused by two things. Firstly, the education vision is not aware of seeing art as universal human capacity which shapes students into a complete human being (having intellectuality, spirituality, morality, and aesthetics). Secondly, the supplied teachers are not given sufficient provisions in order to grow the art 
sensitivity and give experience of art comprehension to the students.

Teachers with sufficient knowledge and skills create a positive learning environment and leave significant impact on children in music classes. Effective teachers demonstrate a variety of teaching styles and strategies to make the learning process more meaningful [4]. Teaching art in Tamansiswa is a formal education for the students so that they deeply understand the ethic and esthetic values. Therefore, any activities deling with art or art education in formal school give meaning for those students in the future. Educating the children as well as developing their potentials and creativity are parents' dedication towards their children. The high social values in society can be reached by giving better education for the children in some certain ways such as religious aspect and art education. Hence, through the design and shape of arts, the cultural values of a nation can be measured [6]. By adopting principle of bringing the children to their own culture, Tamansiswa prioritize art lesson since it was founded until today.

In the process of education should know the purpose of education is Human Excellence (human virtue). So far, only one teacher to teach the subject matter, but this time the teacher had to teach character in their subject area. Thus, learners experience the learning process itself. Centered learning students means students participated in the learning process as much as possible. Learners are not only intelligent, but they also have good qualities [7]. Elementary schools can also range from kindergarten to eighth grade". At the age of students taught in various aspects of discipline, skills, and behaving and know the environment. In addition, through education in primary school students expected to socialize good with his friend, teachers, and the community. Because of that basic education very important for learners [1]. Many people say art education affects children individual development, especially building virtuous character. Though art, children are stimulated to imagine the life values. Through that way, they will understand the life values which finally lead them to broad-mindedness. If the children have capability to value the life, they will be a wise and useful human being for the society's life.

Generally, education is seen as an effort for developing and shaping one's character. Therefore, education needs to pay attention to the development of children's characteristics through habit training, art education, or other skills. Continuously, education should be able to develop the children's character holistically, not only some parts of the competencies they have. That is why education has a very important function and role towards children's skill development, since education is able to support the children for reaching spiritual maturity and intellectuality. Through that way, education can give adequate supply towards the tasks that the children will face when they have already finished their study.

Character education can be initiated at any grade level. It is important to set a strong foundation during the earlier grades and to reinforce and build upon that foundation during the later grades. To be effective, character education must include the entire school community and must be infused throughout the entire school curriculum and culture [2].

Art education in Tamansiswa that is included in intracurricular activities gives positive effect towards the shaping of children's character. After getting the scheduled art lesson, the children will have virtuous character, confidence, discipline, capability to cooperate with others or mutual assistance, ethics and aesthetics; independent, intellect, creative and open-minded attitude. Such thing can occur within intra-curricular activities in which the students do not limit their role as observers. They tend to take roles as the doers so that they are able to interpret, perceive, and carry out the learning activities. In other words, the students will have ethic and aesthetic sensitivity.

The art education in Tamansiswa is different from art education provided in extracurricular programs. When it is included in extracurricular program, art education is not compulsory for students to join and, moreover, the focus is more like appreciation activities. Therefore, that kind of education only affect the way the students adore art, love art, appreciate art, criticize art, value art, develop interest towards art, and furthermore it becomes a recreation event or entertainment. In other words, it only makes the students have aesthetic sensitivity.

Art, as a medium of education in Tamansiswa Yogyakarta, has an important position. It does not only serve as an object to be appreciated by the students, but also functioned as a kind of software contributing to determine education success. As part of regular education in Tamanasiswa, art education does not aim at resulting artist candidates, but aims at resulting students who have intellectual capability as well as sense sensitivity. Art which has regularity (wirama), tenderness (wirasa), and aesthetics (wiraga) will strongly affect the shaping of the children's character. Basically, art education is a way that can be go through as an effort for having the students mature and cultured. Art education is one way to culture human and make them complete. Complete human beings will not be perfectly shaped without art education since art education put the basis on the emotional values as harmonization towards intellectual values [3].

In addition to its role dealing with maturing and culturing subjected students as the aim of regular education, art education has meaningful values as a medium for building or shaping character. According to Herbert Read, art education has some fundamental roles comprising: (a) as a coordination among various perceptions and sensations; (b) as a coordination among various perceptions and sensations in relation to environment; (c) as a medium to express feeling asserted in a certain form; (d) as a medium to express soul experience or to express part or the entire sub-consciousness; and (e) as a medium to express ideas asserted in a certain form [11].

According to Indria Laksmi Gamayanti, art involves emotion and feeling, interpersonal skill, concentration and cognition, feeling and the atmosphere of involvement, communication skill, and motoric skill [5]. Emotion and feeling will make creativity grow in doing arts; interpersonal skill will make the true artistic grow; concentration and 
cognition will encourage the creative process; feeling and atmosphere of involvement will emerge comprehension (greget) in the form of art; communication skill will result a communicative artwork (the message delivered through artwork will be comprehended by art lovers); and motoric skill will result skill.

"Personality is a psychological totality which portrays the sides from genetics (parents and ancestors) and the sides obtained from education, life experiences, and environment [12]. Genetic factors such as talent, intelligence, and temper (Javanese people call it watek, not watak; temper is something difficult to change). In addition, the sides obtained from education that can be shaped and the sides obtained from life experiences include knowledge, skill, character (this thing can be changed). Therefore, personality is a combination between temper (watek) and character (watak).

Sariswara is a method of teaching children through art in order to habituate them with every aesthetics by combining all the existed sense experience including hearing, sight, physical movement, and feeling. In a glance, it looks like integrated learning model which is very famous today. However, there is a difference if it is studied in detail. The combination of the senses makes the aforementioned method more complete and deep for the children. In addition to that, this method completes the combination in a story framework which is embedded in the children selves until they become adult. The story taken from the local people stories and heroism function as if it gives bonus though building poles of several characters including mutual assistance, respecting each other, loving each other, giving positive implications for every being, and loving the nation deeply. The basis of Sariswara method is combining songs, literature, and stories, as what has been existed in Indonesian traditions. Based on the aforementioned explanation, this chapter will cover the description to what extent Sariswara method implemented in art education in Tamansiswa Yogyakarta and its relation to building the students' character. The discussion will be categorized into two subchapters, i.e.: (1) Sariswara learning method in Tamansiswa Yogyakarta, and (2) the effect of Sariswara learning method towards the students' characters.

\section{METHODS}

This research is a qualitative one with full and in-depth observation towards a certain object with certain period of time. In observing the phenomenon, the researcher did not only seek for and collect the data, but immediately classified the data, processed, and analyzed them. The theoretical framework was build based on the indicators figured out in the field, not before the research was done or planned. It aimed at having the observation full and not obstructed by the theoretical aspects that the researcher planned. Therefore, the data understanding, comprehension, and analysis were based on the accumulation of the researcher's knowledge and empirical experience [8].

The subject of this study was a grade four teacher who taught arts and culture subjects and 25 students at Tamansiswa School. The object of this research is art and culture lessons. The method of data collection was done by literature study, interviewees, and observers and then selected many times and separated between staples and supporting materials and / or comparison; he further classified it into 3 groups of data, namely: (1) data on Tamansiswa learning, (2) data on Tamansiswa education curriculum, and (3) data on interviews. The nature of the analysis of this research is descriptive qualitative, namely the analysis in the form of exposure to the results of the study in a comprehensive / in-depth description, not statistical analysis. The analysis is presented in the form of a systematic description. Structured observations are carried out by involving observations in every art and culture class. Video recorders are used to record the entire learning process to find out the integrated character values in the learning process. Observation sheets are also used to write what happened during observations.

\section{RESULTS AND DISCUSSION}

\section{A. Sariswara Learning Method in Tamansiswa}

Sariswara method, proposed by Ki Hajar Dewantara, was firstly applied in Tamansiswa Yogyakarta. This method is expected to be the main medium for shaping the student's character, or it is called Ambuka Raras Angesti Wiji in Javanese term, meaning that singing Javanese poetry is the point of education. In that era, there were various works of Javanese poetry for playing (dolanan) made by the founders (Empu) of Tamansiswa such as Ki Hadisukatno with his work entitled langencarita. The concept of this learning method is not actually for Tamansiswa only, but also for general basic learning dealing with Indonesian culture which gets appropriate ethics and attitude to be role model in regular school. The implementation of this method started in Taman Indria in Tamansiswa Yogyakarta. In other words, the school is equivalent to kindergarten level. It shows that this method is significantly important to base children early education by emphasizing on ethical behaviors in the future life. Indonesia consists of various cultural characters, especially Javanese culture which has strong ethics and attitudes.

This chapter will explain how the system of Sariswara method implementation in art lesson in the first school of Tamansiswa, the activities of which were the teacher came to the class, greeted the students, and taught them simple Javanese poetry (tembang) that was produced by the teacher himself/herself. The Javanese poetry was sung in every first meeting of the teacher's coming which aimed at making students always remember and memorize the rules inserted in the poetry. Sometimes, in common school lessons, the teacher only delivered the rules directly about how to have a certain attitude and how to behave in the process of learning. Through that way, the students heard the rules only once or in a glance that made them find it difficult to understand the teacher's purposes dealing with the rules. The aforementioned general method is different with this Sariswara method. Here, all the rules were delivered through Javanese poetries (tembang) that were easily memorized by the students and compulsory to be sung when starting the lesson. In addition to that, the way the students sang them was added by certain movements showing certain behaviors taught by the teacher. One example of the opening tembang in the class when starting the lesson was the following:

Opening tembang (poetry song in Javanese): 
Siji loro telu tangane sendeku

Meringake bu guru, menawa didangu

Papat nuli limo, lenggahe sing tata

Aja pada sembrana, mundak ora bisa

Translation:

One two three, the hands are on the table.

When the teacher is explaining, students have to listen

So when the teacher asks, they are able to answer.

Students should be well-regulated by sitting orderly

Do not behave as you like, or you will not understand the lesson materials.

Implementation with movements:

Siji loro telu tangane sendeku

(with sendeku movement)

Meringake bu guru, menawa didangu

(with the hands clenching under the ears)

Papat nuli limo, lenggahe sing tata

(while sitting orderly)

Aja pada sembrana, mundak ora bisa

(with the hands signing "I cannot")

Viewing from the content of the tembang above, there is an advice dealing with the rules or urges for the students to behave appropriately before the lesson started by having position hands on table (in Javanese, it is called sendeku). The next meaning of the tembang is giving suggestion for students to pay attention to the teacher's explaining of the lesson materials by sitting orderly and neatly as well as avoiding behaving inaptly which causes them difficult to understand the materials delivered by the teacher.

According to the aforementioned explanation, Swariswara method is a quite complex. In conveying the urges and rules to the students, Javanese poetry (tembang) and movements were created so that the students easily memorize and always remember the content asserted in the tembang. Furthermore, the students felt that the rules were something interesting that there was no force bound to them. In other words, it is nowadays called "playing while learning". During theprocess of learning, the teacher indeed needed a great deal of creativity. Ki Hajar Dewantara at that time always suggested every teacher to observe the students' behaviors and adapt to the learning environment. Actually, this method cannot be only implemented in art lesson, but also combined with other themes of the lesson materials such as literature, counting, and other kinds of lesson which were famous as integrated learning or thematic learning. It depends on the teacher as the one who is able to create an interesting tembang in line with the theme being taught.

Secondly, the following explanation is the example of art learning activities using Sariswara method. First of all, the students were invited to go out from the class to the school garden by making a line while the teacher instructed them to see the garden and acknowledge some animals there, for example the butterflies which descended upon the flowers and the caterpillars on the leaves. The Javanese poetry (tembang) created by Tamansiswa team at that time were entitled kupu kuwi and ulat keket. The followings are the content of the tembang:

\section{Kuрu kuwi}

Tak incupe Kupu kuwi, mrono mrene ngewuhake

Pancen nyata kupu kuwi, banjur mabur sak gelemene

\section{Meaning:}

When the butterfly was about to be caught, it goes hither and thither that makes others confused

Indeed, in fact, that butterfly is, after that it goes as it likes

\author{
Uler Keket \\ Uler-uler keket, dichutik molat-molet \\ Ledhul...dhule...jendhul... Ledhul...dhule...jendhul
}

Meaning:

The caterpillar on those leaves, they will move (molat molet) when they are touched.

This learning method implemented took local animals as the theme which was done by introducing the characters of the living animals such as butterflies and caterpillars. The method didnot only teach the students through singing tembang but also provided movements so that the message within the tembang can be delivered clearly. Through Sariswara method, the materials taught were in the form of Solah-bawa which mean movements and songs. Through that way, the students were able to feel, see, sing, and move in order to understand what they experienced. After the outside-class materials, the students were given time to take rest and to have meal and drink. After that, the students came back into the classroom with the teacher. The next class activity was repeating and rejoice the outdoor materials as well as singing the tembang back in front of the class in order to train their confidence and to avoid them forgetting the tembang.

\section{B. Sariswara Method Improve the Children's Characters}

As an educational institution, Tamansiswa has a big role in shaping positive personality of the children since Tamansiswa does not only supply them with knowledge and skill, but also virtuous characters. As everybody knows, art education does not only serve as talent and interest development but also influences the psychological process. It is due to the fact that those branches of art have their own rigid rules. For instance, in dance art, the education values are conveyed through movement expressions; in fine art, the education values are conveyed through line expressions; and in operetta, the education values are conveyed through the story plot, characterization, facial expressions, vocals, and lyrics.

The existence of art in the society is expected to be able to give stimulation towards the types of behaviors which in line with Eastern culture. In Javanese culture, especially in Yogyakarta, the positive behaviors in daily life emphasize on the attitude and manner issues as part of virtuous character 
building. Therefore, through art education, Tamansiswa tried to direct and give provisions towards the children since the early age about the things dealing with ethical issues (manner and character) and aesthetic issues. One of them was operetta which made educational media in Tamansiswa Yogyakarta gave positive effect towards the psychological development of the actors since, in operetta, the actors directly dealt with educational process. In this case, learning was seen as a process with several phases of understanding which were structured and gradual. First of all, the students were faced to a text they had to understand both, its content and meaning. After that, they practiced and memorized the lyrics as well as the songs. At this phase, discipline became the primary modal in order to boost a learning process. If the lyrics and the song had been memorized, they did not have to understand their own roles. Understanding character for every role was necessary so that when they performed, they were able to express the haracter roles through mimic and behaviors as their interpretation. Considering operetta was result of group work, the cooperation between actors was needed in order to get the perfect performance. Despite the aforementioned things, each actor needed to have independence in order to live the characteristics of the characters they played.

Based on the description above, it can be concluded that Sariswara method has pedagogical values that strongly affect the children's character building. The character covers:

\section{a) Virtuous Character}

Since they are in early childhood, the students were taught attitude and manner which was done by respecting older peoplein their environment, one of which was their teacher. Some of the examples were greeting all the teachers, both the ones who directly taught them and not; greeting friends including the senior ones; and greet anybody in their surroundings including at home. It is the real form of virtuous character building.

\section{b) Confidence}

Confidence came because the students had been accustomed to Sariswara learning. Through the habit of singing tembang and moving in order to understand certain material as well as performed it in front of the class or on stage, the children automatically got accustomed to confidence which grew continuously.

\section{c) Discipline}

The actualization of discipline dealt with students' activities at school, including discipline to come to the class, discipline in the movements that the teacher provides, and discipline in singing the tembang in every process of teaching and learning activities.

\section{d) Togetherness}

Togetherness was reflected through the relationship between teachers and students in order to make the learning process runs well. Cooperation was also needed by the doers in order to build togetherness for achieving the target of the performance.

\section{e) Ethics and Aesthetics}

In acting out the characters, the students directly got lesson dealing with polite manners or unggah-ungguh. In addition, in performing the movements, lyrics, and songs, the students were expected to involve the psychological expressions of character's internal condition that they played, so that the performance could reflect the aesthetic values.

\section{f) Independence}

Independence was in order to strengthen the intention to perform in front of a lot of people so that confidence emerged.

\section{g) Intelligence}

Intelligence was necessary in order to understand songs, manuscript, lyrics, rhythms, movements or even interpret a Javanese poetry (tembang).

\section{h) Creative}

Creative children are always aware towards the situation and condition they face on the stage so that they are able to make improvisation of what happens out of the script. after conducting trials and observations through three stages, it is important to present summary of findings in tables. The results of stage I analysis with code T1, stage II with code T2, stage III with the code $\mathrm{T} 3$, as presented in table 1 as follows:

TABLE I. SUMMARY OF CHARACTER INSERTED

\begin{tabular}{|c|l|c|c|c|}
\hline No. & Character Value & $\mathbf{T}^{\mathbf{1}}$ & $\mathbf{T}^{\mathbf{2}}$ & $\mathbf{T}^{\mathbf{3}}$ \\
\hline 1. & Virtuous Character & $95 \%$ & $90 \%$ & $92 \%$ \\
\hline 2. & Confidence & $88 \%$ & $90 \%$ & $85 \%$ \\
\hline 3. & Discipline & $90 \%$ & $90 \%$ & $90 \%$ \\
\hline 4. & Togetherness & $87 \%$ & $80 \%$ & $86 \%$ \\
\hline 5. & Ethics and Aesthetics & $85 \%$ & $84 \%$ & $88 \%$ \\
\hline 6. & Independence & $82 \%$ & $80 \%$ & $85 \%$ \\
\hline 7. & Intelligence & $86 \%$ & $90 \%$ & $88 \%$ \\
\hline 8. & Creative & $90 \%$ & $83 \%$ & $86 \%$ \\
\hline
\end{tabular}

Based on the research results, it was shown that the final result of the learning process in Tamansiswa Yogyakarta was to result students who were able to understand and employ ethical and aesthetic values in order to form next generation with virtuous character. Therefore, the motto of Tamansiswa does not only prioritize intellectuality but also develop aesthetic and ethical values until they come true.

Attitude and behavior change, as occured in Tamansiswa Yogyakarta, is not found in any other art lesson in any other regular schools since the regular ones emphasize on the art apprecation education. It is because in art apprecation education, students generally act as observers rather than artists.

\section{CONCLUSIONS}

Sariswara is a method to teach children through arts aiming at getting them accustomed to every aesthetics. It is done by combining all the existed senses including hearing, sight, physical movement, and also feeling. In addition to those senses, this method also completes them by combining 
all the elements into one story framework that is embedded into the students from early childhood until they become adult. The story can be taken from local society's stories and heroism which at the same time they give various poles for some characters such as mutual assistance, respecting each other loving each other, giving useful things for every being, and having deep nationality. Sariswara method has several pedagogical that strongly affect the children's character building. The character covers: (1) Virtuous Character, (2) Confidence, (3) Discipline, (4) Togetherness, (5) Ethics and Aesthetics, (6) Independence, (7) Intelligence, (8) Creative.

\section{ACKNOWLEDGMENT}

This research is fully supported by Universitas Negeri Surabaya Research Grant.

\section{REFERENCES}

[1] A.R. Aisyah, "The implementation of character educa-tion through contextual teaching and learning at personality development unit in the sriwijaya university palembang," International Journal of Education and Research, vol. 2, no. 10, 2014.

[2] P. Aynur, "The need for character education", International journal of social sciences and humanity studies, vol 3, No 2, pp. 23-32, 2011.

[3] S. Bastomi, Kebudayaan, Apresiasi Seni, Pendidikan Seni. Semarang: IKIP Semarang Press, 1986.

[4] C. Augustine, and Wong Huey Yi, and C. Wong, "Music Teaching
Readiness among Non-Specialised Music Teachers in Government Preschools," Malaysian Music Journal, vol. 5, No.. 2, pp. 54-69, 2017.

[5] G. L. Gamayanti, Seni Sebagai Pendekatan Psikologis bagi Anak dan Remaja, makalah dalam rangka Hari Anak Nasional, disajikan di Taman Budaya Yogyakarta, 2006.

[6] S. Hadisukatno, and T. Langen, Patiné Arja Penangsang, Yogyakarta: Rake Sarasin, 1964.

[7] S. A. Kamaruddin, "Character Education and Students Social Behavior," Journal of Education and Learning, vol.6, no. (4), pp. 223-230, 2012.

[8] A. B. Lawrence, A. U. Nwanekezi, and C. Williams, "Incorporating collaborative learning strategy as part of an Integrated approach in teaching physics in secondary schools," International Journal of Education, Learning and Development, vol.6, No.5, pp.73-81, 2018.

[9] N. Muhadjir, Metodologi Penelitian Kualitatif, Yogyakarta: Rake Sarasin, 2000.

[10] Nayono, Pendidikan Kesenian dalam Pendidikan dan Pengembangan Sumber Daya Manusia, Peringatan 70 Tahun Tamansiswa, Yogyakarta: Majelis Luhur Persatuan Taman $\neg$ siswa, 1992.

[11] H. Read, Education trought Art. London: Faber and Faber, 1970.

[12] H. S. Soedarsono, Character Building Membentuk Watak, Jakarta: PT. Alex Media Komputindo Kelompok Gramedia, 2004

[13] D. Soeratman, and K. H. Dewantara. Yogyakarta: Proyek Inventarisasi dan Dokumentasi Sejarah Nasional, Direktorat Sejarah dan Nilai Tradisional Depdikbud, 1989. 